Cecile N. Padilla $\cdot$ Miguel D. Fortes $\cdot$ Carlos M. Duarte $\cdot$ Jorge Terrados · Lars KampNielsen

\title{
Recruitment, mortality and growth of mangrove (Rhizophora sp) seedlings in Ulugan Bay, Palawan, Philippines
}

C. Padilla $\cdot$ M. D. Fortes

Marine Science Institute, College of Sciences, University of the Philippines, Diliman, Quezon City 1101, Philippines

C. M. Duarte $\cdot$ J. Terrados $(\bowtie)$

IMEDEA (CSIC-UIB), Grupo de Oceanografía Interdisciplinar, Instituto Mediterráneo de Estudios Avanzados, Miquel Marqués 21, 07190 Esporles, Mallorca, Spain e-mail: jorge.terrados@uib.es

Tel.: +34-971611830, Fax: +34-971611761

L. Kamp-Nielsen

Freshwater Biological Laboratory, University of Copenhagen, Helsingørsgade 51, DK3400-Hillerød, Denmark 


\begin{abstract}
Propagule dispersal, establishment and recruitment to the sapling stage are critical steps in the life cycle of mangroves. Specific (i.e., per capita) rates of recruitment and mortality, and the growth rates of Rhizophora seedlings in three mangrove stands in Ulugan Bay (Palawan, Philippines) were estimated between March 1999 and February 2001. Recruitment and mortality were variable in space and time, with mortality exceeding rates of recruitment at all sites. The specific rates of seedling recruitment and mortality were higher in Buenavista $\left(0.66 \mathrm{y}^{-1}\right.$ and $-1.67 \mathrm{y}^{-1}$, respectively) than in Umalagan $\left(0.05 \mathrm{y}^{-1}\right.$ and $\left.-0.33 \mathrm{y}^{-1}\right)$ and Oyster Bay $\left(0.13 \mathrm{y}^{-1}\right.$ and $\left.-0.24 \mathrm{y}^{-1}\right)$. The annual rate of production of internodes by the main stem was similar at the three sites (5.4-5.5 internodes $\mathrm{y}^{-1}$ ), but the annual rate of elongation of the main stem was higher in Buenavista $\left(10.6 \mathrm{~cm} \mathrm{y}^{-1}\right)$ than in Oyster Bay $\left(7.6 \mathrm{~cm} \mathrm{y}^{-1}\right)$ and Umalagan $\left(5.6 \mathrm{~cm} \mathrm{y}^{-1}\right)$.
\end{abstract}

Keywords Recruitment · Mortality * Growth ·Mangrove seedlings Rhizophora 


\section{Introduction}

Mangrove forests are an important natural resource for coastal communities in tropical countries (Tomlinson 1994), but they are under threat due to widespread degradation and enormous pressures to use the land to support other economic activities, such as aquaculture (Fortes 1988; Adeel and Pomeroy 2002). The sustainable use of mangrove forest requires thorough understanding of the ecological processes by which mangrove forests are affected by, and recover from both natural and man-associated disturbances.

Mangrove species of the family Rhizophoraceae are characterized by vivipary, where the embryo develops into a seedling while still forming part of the fruit attached to the parent tree (Tomlinson 1994). After release, mangrove propagules (the seedling in Rhizophora species) float and are dispersed by water. Propagule dispersal, establishment and recruitment to the sapling stage are critical steps in the life cycle of mangroves (Tomlinson 1994) which determine their capacity to maintain their populations and colonize new habitats.

Propagule supply, predation, wave action, and their capacity to establish before loosing viability are the main processes that determine the recruitment rate of propagules in mangrove stands (Clarke and Allaway 1993; McKee 1995; McGuinness 1997; Clarke et al. 2001). The survival and growth of established mangrove seedlings and their recruitment to the sapling stage are mainly determined by the availability of light and nutrients (Smith 1987a; Ellison and Farnsworth 1993; Duarte et al. 1998) and the sensitivity to physicochemical factors of stress (McKee 1995; McKee 1996; Koch and Snedaker 1997; Youssef and Saenger 1998). However, the dynamics of mangrove seedling populations under natural conditions remains to a large extent unknown.

Several studies, for example, provide estimates of seedling mortality due to predation by crabs, snails, or insects, and of the reduction of seedling growth caused by 
these herbivores (Smith 1987b; Robertson et al. 1990; Ellison and Farnsworth 1993; Ellison and Farnsworth 1996; McGuinness 1997; Minchinton and Dalby-Ball 2001; Sousa et al. 2003), but the actual mortality rate of the seedling population at the mangrove stands where those studies were done is not known. Similarly, there are some estimates of the percentage of propagules on a tree that establish after falling (McGuinness 1997), and of the percentage of caged or tethered propagules lying on the sediment surface that are able to establish after some time (Clarke and Myerscough 1993; McKee 1995) but, what was the recruitment rate of new seedlings to the population in those mangrove stands?. The survival and growth of naturally occurring seedlings has been estimated in different locations (Clarke and Allaway 1993; Osunkoya and Cresse 1997) but no simultaneous estimates of the recruitment rates were done (but see Tamai and Iampa 1988).

The objectives of this study were to estimate (1) the specific (i.e., per capita) recruitment and mortality rates, which are the basic demographic variables needed to characterize the dynamics of any population and to evaluate its capacity to recover from perturbations, and (2) the average growth rates of naturally-occurring populations of mangrove seedlings. To this end we selected three populations of Rhizophora seedlings located in three different sites within Ulugan Bay (Palawan island, Philippines). We focused on Rhizophora species (R. apiculata, R. mucronata) for they are the main constituents of the mangrove stands in Ulugan Bay, which represent almost $50 \%$ of total mangrove cover in Palawan, and $15 \%$ of that in the whole Philippines (Fortes and Fazi 2000), and they are mangrove species widely used in afforestation programmes in SE Asia (Field 1998).

\section{Materials and methods}


Ulugan Bay is located on the western coast of Palawan (Fig. 1), a Philippine island which was declared as a Biosphere Reserve by UNESCO Man and Biosphere Programme in 1991 (Kuijper 2003). This $71 \mathrm{~km}^{2}$, shallow bay, which harbors 790 ha of mangroves and 1200 ha of coral reefs and seagrass beds, is considered one of the most significant coastal ecosystems of Palawan. The Bay is the main source of livelihood for local population (6,000 inhabitants) and the most significant source of fish protein of Puerto Princesa City, the capital of Palawan Province. The uplands of the Bay are still heavily forested but lowlands have been cleared for agriculture and human settlement (Fazi and Flewwelling 2000). Part of Ulugan Bay is included in the Puerto Princesa Subterranean River and National Park, one of the two Natural World Heritage Sites in the Philippines. The presence of indigenous populations confers to Ulugan Bay a high cultural importance (Fazi and Flewwelling 2000). Ulugan Bay was chosen by the UNESCO Coastal Zone and Small Islands (CSI) endeavour to implement, with the support of the United Nations Development Programme, inter-sectoral activities to promote the sustainable development of the coastal zone (Kuijper 2003). In addition of being important fishing grounds, mangrove forests in Ulugan Bay are exploited for firewood and charcoal production (Rivera-Guieb 2000), which result in community structures dominated by small-sized trees (Fortes and Fazi 2000).

Palawan climate is characterized by a wet and a dry season: heavy rainfall occurs from May to October during the southwest monsoon, but the weather turns increasingly dry afterwards and there is usually little or no rain from January to April. Mean monthly temperature varied between $23.5^{\circ} \mathrm{C}$ and $24.6^{\circ} \mathrm{C}$ in $1999-2000$, while monthly rainfall peaked $\left(>4001 \mathrm{~m}^{-2}\right)$ in November and December (Fig. 2). The frequency of tropical cyclones hitting Palawan is low; however, in December 1998 the 
Ulugan Bay area was hit by the strongest typhoon recorded which caused extensive damage to the forests and coral reefs (Fortes and Fazi 2000).

Three study sites were chosen within Ulugan Bay to represent the range of sediment conditions naturally available in the mangrove stands inside the bay (Fig. 1): (1) Buenavista, located on the eastern coast of the bay near its mouth, is exposed to wave action and the substratum is a mixture of sand and rocks $(\%$ silt, particle size $<63$ $\mu \mathrm{m}: 3.4 \%$ of sediment dry weight), while the sediment in (2) Umalagan, in the southern end of the Bay, is muddy sand (\% silt: $5.8 \%$ of sediment dry weight); and (3) Oyster Bay is a narrow inlet on the western side of the bay sheltered from wave action and the substratum is deep, black mud (\% silt: $14.2 \%$ of sediment dry weight). Rhizophora apiculata BL., Rhizophora mucronata Lamk., and Bruguiera gymnorrhyza (L.) Lamk. are the dominant mangrove species in Ulugan Bay (Fortes and Fazi 2000), and both Rhizophora species were present at the three mangrove stands chosen.

A permanent plot was established in each site at the beginning of the study (March 1999 in Buenavista and Umalagan, May 1999 in Oyster Bay). The plots were scaled to include more than 100 Rhizophora seedlings so that reliable estimates of seedling recruitment and mortality could be obtained. The permanent plots were rectangular in shape with one of their long sides parallel to the seaward edge of the mangrove stands and extending inside them. Plot dimensions were $50 \mathrm{~m}$ x $45 \mathrm{~m}$ in Buenavista and $30 \mathrm{~m}$ x $25 \mathrm{~m}$ in Umalagan, while the Oyster Bay plot was the smallest. We could not discriminate between $R$. apiculata and $R$. mucronata seedlings for they had the same morphology. Seedling and sapling density inside the permanent plots at the initiation of the study was 0.06 plants $\mathrm{m}^{-2}$ in Buenavista, 0.14 plants $\mathrm{m}^{-2}$ in Umalagan, and higher than 0.19 plants $\mathrm{m}^{-2}$ in Oyster Bay. All Rhizophora seedlings present inside the permanent plots were tagged with a numbered label, the number of 
internodes of the main stem counted, and the height of the main stem measured. These measurements were repeated every 2-3 months until August 2000, with an additional measurement made in February 2001, and were used to calculate seedling growth in terms of both number of internodes produced along the main axis and the elongation of the main stem during each time interval. The annual rate of production of internodes and elongation by the main stem was calculated by adding the growth accumulated at each time interval during the study and standardization of the resultant amount to one year.

The number of new, dead, and missing seedlings was recorded at each sampling event to estimate seedling recruitment and mortality. Young seedlings (with 3 or less internodes on the main stem) that had no tag were classified as new seedlings recruited into the plots; any other untagged seedling present inside the plots was assumed to have been missed in previous visits. Specific (i.e., per capita) recruitment and mortality for each time interval between two consecutive sampling events were calculated using the equations

$$
\begin{gathered}
\left.R_{t+1}=\ln \left(\left(\left(N_{t}+N R_{t+1}\right) / N_{t}\right)\right) / \Delta t\right) \\
\left.M_{t+1}=\ln \left(\left(\left(N_{t}-D_{t+1}\right) / N_{t}\right)\right) / \Delta t\right)
\end{gathered}
$$

, where: $R_{t+1}=$ Specific recruitment rate for the time interval $\left(\mathrm{d}^{-1}\right)$

$M_{t+1}=$ Specific mortality rate for the time interval $\left(\mathrm{d}^{-1}\right)$

$N_{t}=$ Total seedling population at beginning of the time interval

$N R_{t+1}=$ No. of new recruits at the end of the time interval

$D_{t+1}=$ No. of dead seedlings at the end of time interval

$\Delta t=$ No. of days elapsed from $t$ to $t+1$

, and averaged during the study period and multiplied by 365 days to calculate annual specific rates. 
At the initial sampling event not only the number of internodes of the main stem of all Rhizophora seedlings present inside the permanent plots were counted but also those of all Rhizophora saplings and young trees (less than $5 \mathrm{~m}$ in height). The number of older trees was also counted, but the number of internodes of the main stem of each of them was not for bark growth renders them invisible. The age structure of the population of Rhizophora plants inside each permanent plot was obtained by calculating the age in years of each plant as

number of internodes / Mean annual internode production rate

, where the mean number of internodes produced per year was that obtained from tagging. This procedure to estimate plant age is based on the concept of plastochrone interval (Erikson and Michelini 1957), the time interval between the production of two consecutive structural modules (e.g. leaves, internodes, roots) by higher plants. Knowledge of both the average duration of the plastochrone interval of a certain module and the number of modules produced by a plant during its life span allows the estimation of plant age in time units (Duke and Pinzón 1992; Duarte et al. 1999). The rather constant nature of the plastochrone interval of the internodes on the main stem of Rhizopora species (Duarte et al. 1998) facilitates this task.

Three branches from each reproductive tree at each permanent plot were examined to count the number flower scars (cf. Coulter et al. 2001) present in a known set of internodes, and the flowering rate (number of flowers branch ${ }^{-1}$ year $^{-1}$ ) was calculated as (number of flower scars/number of internodes)*(Mean annual internode production rate)

(Coulter et al. 2001). 
The nutrient content of the leaves of Rhizophora was used as an indicator of nutrient availability in the sediment (Boto and Wellington 1983; Duarte et al. 1998). We haphazardly collected 20 leaves from adult Rhizophora trees at each site, which were oven-dried at $60^{\circ} \mathrm{C}$ for at least 24 hour and kept in plastic bags with silica gel until nutrient analysis were done. Three individual leaves from each set were chosen haphazardly and total carbon and nitrogen were determined using a Carlo-Erba NA$1500 \mathrm{CHN}$ analyzer. Total phosphorus was determined spectrophotometrically after $1 \mathrm{hr}$ ignition of leaf material at $550^{\circ} \mathrm{C}$ and $15 \mathrm{~min}$ of boiling of the ash in $1 \mathrm{~N} \mathrm{HCl}$ (Andersen 1976).

Sediment conditions at the study sites were characterized by the content of organic matter, the redox potential, and the concentration of sulfide, ammonium, nitrate and phosphate in pore waters. Ten sediment samples were collected at each site and sampling event using plexiglass tubes ( $4 \mathrm{~cm}$ internal diameter) that were inserted $10 \mathrm{~cm}$ into the sediment by hand during low tide. Only sediment cores $4-6 \mathrm{~cm}$ in length could be collected at Buenavista due to the thin layer of sediment overlying rock outcrops. Within 2 hours after collection each sediment core was cut longitudinally in two unequal parts: one third of the core was used to extract pore water while the other two thirds were air-dried first, then oven-dried at $60^{\circ} \mathrm{C}$ for 24 hours, and weighed. Dry sediment samples were combusted at $550^{\circ} \mathrm{C}$ during 4 hours and weighed to calculate the content of organic matter of the sediment as percentage of sediment dry weight. Pore water was extracted in vacuum, which minimizes oxygen presence, in less than 1 minute using a filtration manifold and $47 \mathrm{~mm}$ in diameter Whatman GF/C filters and collected directly into $20 \mathrm{ml}$ vials which contained either $50 \mu \mathrm{l}$ of $1 \mathrm{M} \mathrm{Zn}\left(\mathrm{CH}_{3} \mathrm{COO}\right)_{2}$ and $50 \mu \mathrm{l}$ of $1.2 \mathrm{M} \mathrm{NaOH}$ as preservatives for sulfide analyses, or $50 \mu \mathrm{l}$ of $1.8 \mathrm{M} \mathrm{H}_{2} \mathrm{SO}_{4}$ as preservative for ammonium, nitrate and phosphate analyses. Sulfide was analyzed 
following Eaton et al. (1995), and ammonium, nitrate and phosphate were analyzed using a Rapid Flow Analyzer Alpkem ${ }^{\circledR}$ (ALPKEM 1990). Redox potential of the sediment at a depth of $-4 \mathrm{~cm}$ was measured using a Pt electrode and a $\mathrm{Ag} / \mathrm{AgCl}$ reference electrode with $3 \mathrm{M} \mathrm{KCl}$ electrolyte. The status of the electrode was checked before each measurement using a redox standard solution, and millivolt readings were corrected to obtain $\mathrm{E}_{\mathrm{h}}$ values by adding $+207 \mathrm{mV}$ (Crison ${ }^{\circledR}$, Spain).

\section{Results and Discussion}

The recruitment of seedlings was highly variable at the three sites. The period of maximum recruitment extended from May to October 1999 in Buenavista and from May to July 1999 in Oyster Bay, while no seedlings were recruited to the Umalagan plot during this period of time (Fig. 3). The following year, however, seedling recruitment in Umalagan occurred from May to August. Propagule fall in Southern Thailand Rhizophora apiculata forests starts in February, peaks from May to July, and ends in September, while seedling recruitment occurs from March to September with a peak in April-June (Christensen and Wium-Andersen 1977; Tamai and Iampa 1988).

Seedling mortality was also highly variable in Ulugan Bay, with maximum mortality rates recorded from October 1999 to February 2000 in Buenavista, March to May 1999 in Umalagan, and February to May 2000 in Oyster Bay (Fig. 3). Tamai and Iampa (1988) found that death of $R$. apiculata seedlings can occur any time during the year but peak events occur just after seedling establishment (June-July), and is more frequent from November to April.

The population at Buenavista showed a higher dynamics than that at the two other sites as evidenced by the continuous recruitment of new seedlings during the whole period of the study (Fig. 3), which resulted in a higher proportion of younger 
plants, and higher daily specific recruitment rates than those of the populations in Umalagan and Oyster Bay (Table 1, Fig. 4). Continuous recruitment of seedlings in Buenavista does not seem to be related to a higher production of propagules at this site (Table 1). The median age of the initial population of Rhizophora seedlings tagged in Buenavista was slightly lower than that at Oyster Bay and Umalagan (Table 1). The Buenavista population had a higher percentage of young (age $<1$ year) seedlings than the populations at Oyster Bay and Umalagan (Table 1, lower quartiles; Fig. 4), while this last population had a higher percentage of old (age $>5$ years) plants (Table 1, upper quartiles; Fig. 4). Buenavista site appears more exposed to wave effects than the other two sites, as evidenced by the lower percentage of silt of the sediment there, which suggests that the mechanical disturbance associated with wave exposure might be one of the reasons why mean daily specific mortality rate tended to be higher in Buenavista than in Umalagan and Oyster Bay (Table 1). Mechanical disturbance associated with water movement has been identified as one of the causes of mortality of established mangrove seedlings (Thampanya et al 2002).

The mean annual specific recruitment rate was $0.66 \pm 0.38(\mathrm{SE}) \mathrm{y}^{-1}$ in Buenavista, $0.05 \pm 0.03 \mathrm{y}^{-1}$ in Umalagan, and $0.13 \pm 0.06 \mathrm{y}^{-1}$ in Oyster Bay, while the mean annual specific rates of mortality were $-1.67 \pm 1.08 \mathrm{y}^{-1},-0.33 \pm 0.12 \mathrm{y}^{-1}$, and -0.24 $\pm 0.05 \mathrm{y}^{-1}$, respectively, in the three sites. These results show that mortality was always higher than recruitment in the three populations during the period of the study. The difference between recruitment and mortality was highest in Buenavista $\left(-1.01 \mathrm{y}^{-1}\right)$, and decreased in Umalagan $\left(-0.19 \mathrm{y}^{-1}\right)$ and Oyster Bay $\left(-0.11 \mathrm{y}^{-1}\right)$. These differences should not be considered a direct evidence of population decline since the observational period (1.5 years ) was smaller than the median age of the seedlings (2.2-2.9 years), and because our results also suggest that both recruitment and mortality may show high 
inter-annual variability both in strength and time of the year (Fig. 3). Periods of net decline in seedling abundance may be compensated by others of net increase in favorable years. Annual cohorts of Avicennia marina seedlings also show large differences in mortality during consecutive years (Clarke and Allaway 1993).

The growth rate of Rhizophora seedlings in Buenavista showed an unimodal annual pattern, both in terms of internode production and elongation of the main stem, with maximum values in May and minimum values in October-February (Fig. 5). No clear temporal trends were observed in the other two sites, and correlations between seedling growth rate, air temperature and rainfall were not significant in any of the sites. Seedling and sapling density in Buenavista was lower than that at the other two sites which leads us to speculate that the clear unimodal pattern of seedling growth there might be driven by the seasonal change in light availability for the maximum growth rates were registered at the end of the dry season when rainfall was low and solar radiation likely high. Compared to Buenavista, more closed canopies in Umalagan and Oyster Bay might provide more constant light availability which would render no clear seasonal patterns of seedling growth. Unfortunately we did not measure light availability at the three plots.

The daily rate of production of internodes by the main stem was similar at the three Rhizophora stands studied (Table 1); the daily rate of elongation of the main stem, however, was highest in Buenavista and lowest in Umalagan. The annual rate of production of internodes by the main stem was $5.5 \pm 0.7$ (SE) internodes $\mathrm{y}^{-1}$ in Buenavista, $5.4 \pm 0.4$ internodes $\mathrm{y}^{-1}$ in Umalagan, and $5.5 \pm 0.3$ internodes $\mathrm{y}^{-1}$ in Oyster Bay, while the annual rates of elongation were $10.6 \pm 2.2 \mathrm{~cm} \mathrm{y}^{-1}, 5.6 \pm 0.7 \mathrm{~cm} \mathrm{y}^{-1}$, and $7.6 \pm 1.0 \mathrm{~cm} \mathrm{y}^{-1}$, respectively. These results give support to previous contentions 
(Duarte et al. 1998) which consider the number of internodes produced by the main stem a highly conservative feature of the development of Rhizophora species.

The rates of production of internodes and elongation of the main stem of Rhizophora in Ulugan Bay are in the lower end of the values reported previously (5.2 to 8.9 internodes $\mathrm{y}^{-1}, 6$ to $70 \mathrm{~cm} \mathrm{y}^{-1}$; Tamai and Iampa 1988; Duke and Pinzón 1992; Duarte et al. 1998; Duarte et al. 1999; Kitaya et al. 2002; Thampanya et al. 2002). Additionally, the concentration of nitrogen in the leaves of adult trees of the three stands (Table 1) are at the lower end of the range of values reported from other Rhizophora sp stands elsewhere (0.7 to $1.6 \%$ of dry weight; Onuf et al. 1977; Boto and Wellington 1983; Twilley et al. 1986; Rao et al. 1994; Feller 1995; Duarte et al. 1998), which suggests that growth of Rhizophora seedlings in Ulugan Bay might be limited by nitrogen availability. The growth of Rhizophora mangle trees with concentrations of nitrogen in the leaves similar or higher (0.9-1.6 \% of dry weight) to those found in Ulugan Bay has proven to be limited by nitrogen availability (Feller et al. 2003a; Feller et al. 2003b). Phosphorus limitation of $R$. mangle growth has been demonstrated only at concentrations of phosphorus in adult leaves below $0.04 \%$ of leaf dry weight (Feller 1995; Feller et al. 2003b), which are lower than those found in adult trees in Ulugan Bay (Table 1).

The content of organic matter of the sediment increased from Buenavista to Umalagan and Oyster Bay while the redox potential at a sediment depth of $4 \mathrm{~cm}$ became more negative (Table 1), which indicates that the sediment in Buenavista was less reduced than those at the other two sites. Sulfide concentration in pore water tended to be lower in Buenavista than in the other sites but the difference was not significant. Although ammonium, nitrate and phosphorus concentration in pore water were not different among the sites, the concentration of nitrogen in the leaves of adult trees were 
lower in Oyster Bay than in the other sites (Table 1). Sulfide can inhibit nitrogen uptake and reduce the growth of salt marsh plants (Koch et al. 1990), and affect negatively the physiology of mangrove seedlings (McKee 1996; Youssef and Saenger 1998). The lower concentration of nitrogen in the leaves of adult trees in Oyster Bay could be related with the more reduced sediment conditions in this site. Flower production of adult trees in Oyster Bay was smaller than in the other two sites (Table 1), and could be related to their lower nutrient content in the leaves if nutrient availability affects the production of flowers and fruits (Onuf et al. 1977).

The higher elongation rate shown by Rhizophora seedlings in Buenavista does not seem related with a higher nutrient availability at this site for the content of nitrogen in the leaves of adult trees did not differ significantly $(\mathrm{p}>0.05$, post-hoc Tukey HSD test) from that at Umalagan (Table 1), where seedlings showed the lowest elongation. Additionally, the more reduced sediment conditions in Oyster Bay do not seem to have a large effect of seedling growth for the elongation rate of the seedlings there was not different from that at Umalagan. Overall evidences suggest that sedimentary conditions do not seem to be driving the differences in seedling growth between the study sites, and reinforces our previous contention that differences in light availability might be behind the differences in seedling growth among the stands. Light availability is well known to affect growth of mangrove seedlings and their recruitment to the sapling stage (Smith 1987a; Tamai and Iampa 1988; Clarke and Allaway 1993; Clarke 1995; Osunkoya and Creese 1997; Minchinton 2001; Ball 2002).

In summary, our results show that recruitment and mortality in natural populations of Rhizophora seedlings are highly variable in space and time, with mortality exceeding rates of recruitment. In addition to considering the physicochemical conditions and biological interactions that allow the recruitment of mangrove 
seedlings to the sapling stage (cf. Clarke and Allaway 1993; Sousa et al. 2003), modelling of the capacity of mangroves to maintain their populations and recover from both natural and man-associated disturbances should contemplate the whole life cycle of mangroves (cf. Clarke 1995), and quantify spatial and temporal dynamics of seedling populations to provide a strong knowledge base for sustainable management of mangrove forests.

\section{Acknowledgements}

This study was performed within the framework of the PREDICT project, funded by the INCO-DC programme of the European Commission (contract number, ERBIC18CT98-0292). We thank Glenda Gollod and the kids at Palawan State University (Mai, Sweetie, Agnes, Aris, Daniel, and Roy) for assistance in the field, Tutu Almonte and Mayor Hagedorn and his staff at Rita Island for accommodation, Jens Borum for the elemental analysis of the leaves, and the seagrass lab staff at MSI Zayda, Day, Hildie, Napo and Roger, and Mike Mapa for enduring support. We thank the comments of the reviewers and Dr. M. C. Ball which helped us to improve former versions of the manuscript.

\section{References}

Adeel Z, Pomeroy R (2002) Assessment and management of mangrove ecosystems in developing countries. Trees 16:235-238

ALPKEM 1990 RFA-Methodologies A303-S202, A303-S170, A303-S020. Alpkem Corporation. Clackamas, Oregon

Andersen JM (1976) An ignition method for the determination of total phosphorus in lake sediments. Water Research 10:329-331 
Ball MC (2002) Interactive effects of salinity and irradiance on growth: implications for mangrove forest structure along salinity gradients. Trees 16:126-139

Boto KG, Wellington JT (1983) Phosphorus and nitrogen nutritional status of a northern Australian mangrove forest. Mar Ecol Prog Ser 11:63-69

Christensen B, Wium-Andersen S (1977) Seasonal growth of mangrove trees in southern Thailand. I. The phenology of Rhizophora apiculata Bl. Aquat Bot $3: 281-286$

Clarke PJ (1995) The population dynamics of the mangrove Avicennia marina; demographic synthesis and predictive modelling. Hydrobiologia 295:83-88

Clarke PJ, Allaway WG (1993) The regeneration niche of the grey mangrove (Avicennia marina): effects of salinity, light, and sediment factors on establishment, growth and survival in the field. Oecologia 93:548-556

Clarke PJ, Kerrigan RA, Westphal CJ (2001) Dispersal potential and early growth in 14 tropical mangroves: do early life history traits correlate with patterns of adult distribution? J Ecology 89:648-659

Clarke PJ, Myerscough PJ (1993) The intertidal distribution of the grey mangrove (Avicennia marina) in southeastern Australia: The effects of physical conditions, interspecific competition and predation on propagule establishment and survival. Aust J Ecol 18:307-315

Coulter SC, Duarte CM, Tuan MS, Tri NH, Ha HT, Giang LH, Hong PN (2001) Retrospective estimates of net leaf production in Kandelia candel mangrove forests. Mar Ecol Prog Ser 221:117-124

Duarte CM, Geertz-Hansen O, Thampanya U, Terrados J, Fortes MD, Kamp-Nielsen L, Borum J, Boromthanarat S (1998) Relationship between sediment conditions 
and mangrove Rhizophora apiculata seedling growth and nutrient status. Mar Ecol Prog Ser 175:277-283

Duarte CM, Thampanya U, Terrados J, Geertz-Hansen O, Fortes MD (1999) The determination of the age and growth of SE Asian mangrove seedlings from internodal counts. Mangroves and Saltmarshes 3:251-257

Duke NC, Pinzón ZS (1992) Aging Rhizophora Seedlings from Leaf Scar Nodes: A Technique for Studying Recruitment and Growth in Mangrove Forests. Biotropica 24:173-186

Ellison AM, Farnsworth EJ (1993) Seedling survivorship, growth, and response to disturbance in Belizean mangal. Amer J Bot 80:1137-1145

Ellison AM, Farnsworth EJ (1996) Spatial and temporal variability in growth of Rhizophora mangle saplings on coral cays: links with variation in insolation, herbivory, and local sedimentation rate. J Ecology 84:717-731

Erickson RO, Michelini FJ (1957) The plastochrone index. Am J Bot 44 297-305

Fazi S, Flewwelling P (2000) Coastal Resources Management. Ulugan Bay, Palawan Island, The Philippines. Volume I Ecology, culture and socio-economics. UNESCO-UNDP-Puerto Princesa City, Jakarta

Feller IC (1995) Effects of nutrient enrichment on growth and herbivory of dwarf red mangrove (Rhizophora mangle). Ecol Monog 65:477-505

Feller IC, McKee KL, Whigham DF, O'Neill JP (2003) Nitrogen vs. phosphorus limitation across an ecotonal gradient in a mangrove forest. Biogeochemistry $62: 145-177$

Feller IC, Whigham DF, McKee KL, Lovelock CE (2003) Nitrogen limitation of growth and nutrient dynamics in a disturbed mangrove forest, Indian River Lagoon, Florida. Oecologia 134:405-414 
Field C (1998) Rationales and practices of mangrove afforestation. Mar Freshwater Res $49: 353-358$

Fortes MD (1988) Mangrove and Seagrass Beds of East Asia: Habitats Under Stress. Ambio 17:207-213

Fortes MD, Fazi S (2000) Ecology of Ulugan Bay. In: Fazi S, Flewwelling P (eds) Coastal Resources Management. Ulugan Bay, Palawan Island, The Philippines. Volume I Ecology, culture and socio-economics. UNESCOUNDP-Puerto Princesa City, Jakarta, p 1-43

Kitaya Y, Jintana V, Piriyayotha S, Jaijing D, Yabuki K, Izutani S, Nishimiya A, Iwasaki M (2002) Early growth of seven mangrove species planted at different elevations in a Thai estuary. Trees 16:150-154

Koch MS, Mendelssohn IA, McKee KL (1990) Mechanism for the hydrogen sulfideinduced growth limitation in wetland macrophytes. Limnol Oceanogr 35:399408

Koch MS, Snedaker SC (1997) Factors influencing Rhizophora mangle L. seedling development in Everglades carbonate soils. Aquat Bot 59:87-98

Kuijper MWM (2003) Marine and coastal environmental awareness building within the context of UNESCO's activities in Asia and the Pacific. Mar Pollution Bull $47: 265-272$

McGuinness KA (1997) Dispersal, establishment and survival of Ceriops tagal propagules in a north Australian mangrove forest. Oecologia 109:80-87

McKee KL (1995) Seedling recruitment patterns in a Belizean Mangrove forest: effects on establishment ability and physico-chemical factors. Oecologia 101:448-460

McKee KL (1996) Growth and physiological responses of neotropical seedlings to root zone hypoxia. Tree Physiology 16:883-889 
Minchinton TE (2001) Canopy and substratum heterogeneity influence recruitment of the mangrove Avicennia marina. J.Ecology 89:888-902

Minchinton TE, Dalby-Ball M (2001) Frugivory by insects on mangrove propagules: effects on the early life history of Avicennia marina. Oecologia 129:243-252

Onuf CP, Teal JM, Valiela I (1977) Interactions of nutrients, plant growth and herbivory in a mangrove ecosystem. Ecology 58:514-526

Osunkoya OO, Creese RG (1997) Population structure, spatial pattern and seedling establishment of the grey mangrove, Avicennia marina var. australasica, in New Zealand. Aust J Bot 45:707-725

Rao RG, Woitchik AF, Goeyens L, van Riet A, Kazungu J, Dehairs F (1994) Carbon, nitrogen contents and stable carbon isotope abundance in mangrove leaves from an east African coastal lagoon (Kenya). Aquat Bot 47:175-183

Rivera-Guieb R (2000) Socio-Economy of Ulugan Bay. Part I: A socio-economic profile of the communities. In: Fazi S, Flewwelling P (eds) Coastal Resources Management. Ulugan Bay, Palawan island, The Philippines. Volume I Ecology, culture and socio-economics. UNESCO-UNDP-Puerto Princesa City, Jakarta, p 147-188

Robertson AI, Giddins R, Smith III TJ (1990) Seed predation by insects in tropical mangrove forests: extent and effects on seed viability and the growth of seedlings. Oecologia 83:213-219

Smith III TJ (1987a) Effects of light and intertidal position on seedling survival and growth in tropical tidal forests. J Exp Mar Biol Ecol. 110:133-146

Smith III TJ (1987b) Seed predation in relation to tree dominance and distribution in mangrove forests. Ecology 68:266-273 
Sousa WP, Quek SP, Mitchell BJ (2003) Regeneration of Rizophora mangle in a Caribbean mangrove forest: interacting effects of canopy disturbance and stem-boring beetle. Oecologia 137:436-445

Tamai S, Iampa P (1988) Establishment and growth of mangrove seedlings in mangrove forests of southern Thailand. Ecological Research 3:227-238

Thampanya U, Vermaat JE, Duarte CM (2002) Colonization success of common Thai mangrove species as a function of shelter from water movement. Mar Ecol Prog Ser 237:111-120

Tomlinson PB (1994) The Botany of Mangroves. Cambridge University Press, Cambridge

Twilley RR, Lugo AE, Patterson-Zucca C (1986) Litter production and turnover in basin mangrove forests in southwest Florida. Ecology 67:670-683

Youssef T, Saenger P (1998) Photosynthetic gas exchange and accumulation of phytotoxins in mangrove seedlings in response to soil physico-chemical characteristics associated with waterlogging. Tree Physiology 18:317-324 
Table 1. Chemistry of sediment pore water, redox potential and organic matter content of the sediment, nutrient content of the leaves of adult trees, seedling growth and demographic parameters, and flowering rate of adult trees in three Rhizophora stands in Ulugan Bay, Palawan, Philippines. Differences between sites were tested either using one-way Analysis of Variance (F values) or Kruskal-Wallis non-parametric ANOVA (H values). Where ANOVA detected differences between sites, significant contrasts after post-hoc Tukey HSD tests $(\mathrm{p}<0.05)$ are indicated

\begin{tabular}{|c|c|c|c|c|}
\hline & $\begin{array}{l}\text { Buenavista, BV } \\
\text { mean } \pm \text { se }(n)\end{array}$ & $\begin{array}{l}\text { Umalagan, UM } \\
\text { mean } \pm \text { se }(n)\end{array}$ & $\begin{array}{l}\text { Oyster Bay, OB } \\
\text { mean } \pm \text { se }(n)\end{array}$ & \\
\hline $\begin{array}{l}\text { Sulfide, } \mu \mathrm{M} \\
\text { Ammonium, } \mu \mathrm{M} \\
\text { Nitrate, } \mu \mathrm{M} \\
\text { Phosphate, } \mu \mathrm{M} \\
\text { Organic matter, \% of dry weight } \\
\text { Eh at }-4 \mathrm{~cm}, \mathrm{mV}\end{array}$ & $\begin{array}{l}40.9 \pm 8.3(44) \\
156.5 \pm 44.2(41) \\
27.2 \pm 7.9(41) \\
1.0 \pm 0.1(41) \\
7.4 \pm 1.2(35) \\
86 \pm 13(23)\end{array}$ & $\begin{array}{l}99.5 \pm 23.9(47) \\
93.9 \pm 15.4(39) \\
74.2 \pm 44.3(24) \\
1.1 \pm 0.2(39) \\
19.5 \pm 1.7(41) \\
-36 \pm 11(4)\end{array}$ & $\begin{array}{l}152.4 \pm 42.6(50) \\
78.2 \pm 10.2(43) \\
7.7 \pm 1.5(33) \\
1.3 \pm 0.2(41) \\
25.1 \pm 2.6(36) \\
-99 \pm 12(4)\end{array}$ & $\begin{array}{l}\mathrm{H}=2.9, \text { n. s. } \\
\mathrm{H}=0.9, \text { n. s. } \\
\mathrm{H}=1.7, \text { n. s. } \\
\mathrm{F}=1.0, \text { n. s. } \\
\mathrm{H}=44.7, \mathrm{P}<0.01 \\
\mathrm{H}=17.6, \mathrm{P}<0.01\end{array}$ \\
\hline $\begin{array}{l}\text { Leaf nitrogen, } \% \text { of dry weight } \\
\text { Leaf phosphorus, \% of dry weight }\end{array}$ & $\begin{array}{l}0.93 \pm 0.03(18) \\
0.071 \pm 0.002(12)\end{array}$ & $\begin{array}{l}0.96 \pm 0.03(18) \\
0.073 \pm 0.004(12)\end{array}$ & $\begin{array}{l}0.84 \pm 0.03(18) \\
0.066 \pm 0.002(12)\end{array}$ & $\begin{array}{l}\mathrm{F}=4.28, \mathrm{P}<0.05 ; \mathrm{UM}>\mathrm{OB} \\
\mathrm{F}=1.8, \text { n. } \mathrm{s}\end{array}$ \\
\hline $\begin{array}{l}\text { Daily rate of internode production by main stem } \\
\text { (internodes } \mathrm{d}^{-1} \text { ) }\end{array}$ & $0.0173 \pm 0.0033(7)$ & $0.0151 \pm 0.0024(7)$ & $0.0148 \pm 0.0010(6)$ & $\mathrm{F}=0.34, \mathrm{n} . \mathrm{s}$ \\
\hline Daily rate of elongation of main stem, $\mathrm{cm} \mathrm{d}^{-1}$ & $0.0328 \pm 0.0057(7)$ & $0.0169 \pm 0.0029(7)$ & $0.0194 \pm 0.0070(6)$ & $\mathrm{F}=4.97, \mathrm{P}<0.05 ; \mathrm{BV}>\mathrm{UM}$ \\
\hline Flowering rate of adult trees, flowers branch ${ }^{-1} \mathrm{y}^{-1}$ & $1.1 \pm 0.1$ & $1.2 \pm 0.3$ & $0.4 \pm 0.1$ & $\mathrm{H}=3.66$, n.s. \\
\hline Median age, y & 2.2 & 2.9 & 2.6 & -- \\
\hline Lower- Upper quartiles of plant age, y & $0.9-4.0$ & $1.3-5.6$ & $1.4-3.9$ & -- \\
\hline Daily specific recruitment rate, $\mathrm{d}^{-1}$ & $1.8 \times 10^{-3} \pm 1.0 \times 10^{-3}$ & $0.1 \times 10^{-3} \pm 0.7 \times 10^{-4}$ & $0.3 \times 10^{-3} \pm 0.2 \times 10^{-3}$ & $\mathrm{H}=7.35, \mathrm{p}<0.05$ \\
\hline Daily specific mortality rate, $\mathrm{d}^{-1}$ & $-4.6 \times 10^{-3} \pm 2.9 \times 10^{-3}$ & $-0.9 \times 10^{-3} \pm 0.3 \times 10^{-3}$ & $-0.6 \times 10^{-3} \pm 0.1 \times 10^{-3}$ & $\mathrm{H}=5.02$, n. s. \\
\hline
\end{tabular}




\section{Figure legends}

Fig. 1. Location of study sites in Ulugan Bay, Palawan, Philippines.

Fig. 2. Mean monthly air temperature and rainfall in Puerto Princesa - Ulugan Bay area during the study period (Source: Department of Science and Technology Pag-asa, Government of the Philippines).

Fig. 3. Temporal pattern of specific daily recruitment and mortality rates in three Rhizophora stands in Ulugan Bay, Palawan, Philippines.

Fig. 4. Cumulative age distribution of the three Rhizophora populations tagged at the beginning of the study in Ulugan Bay, Palawan, Philippines.

Fig. 5. Temporal patterns of the elongation rate (a) and the rate of production of internodes (b) by the main stem of Rhizophora seedlings in three mangrove stands in Ulugan Bay, Palawan, Philippines. Error bars are \pm 1 SE. 


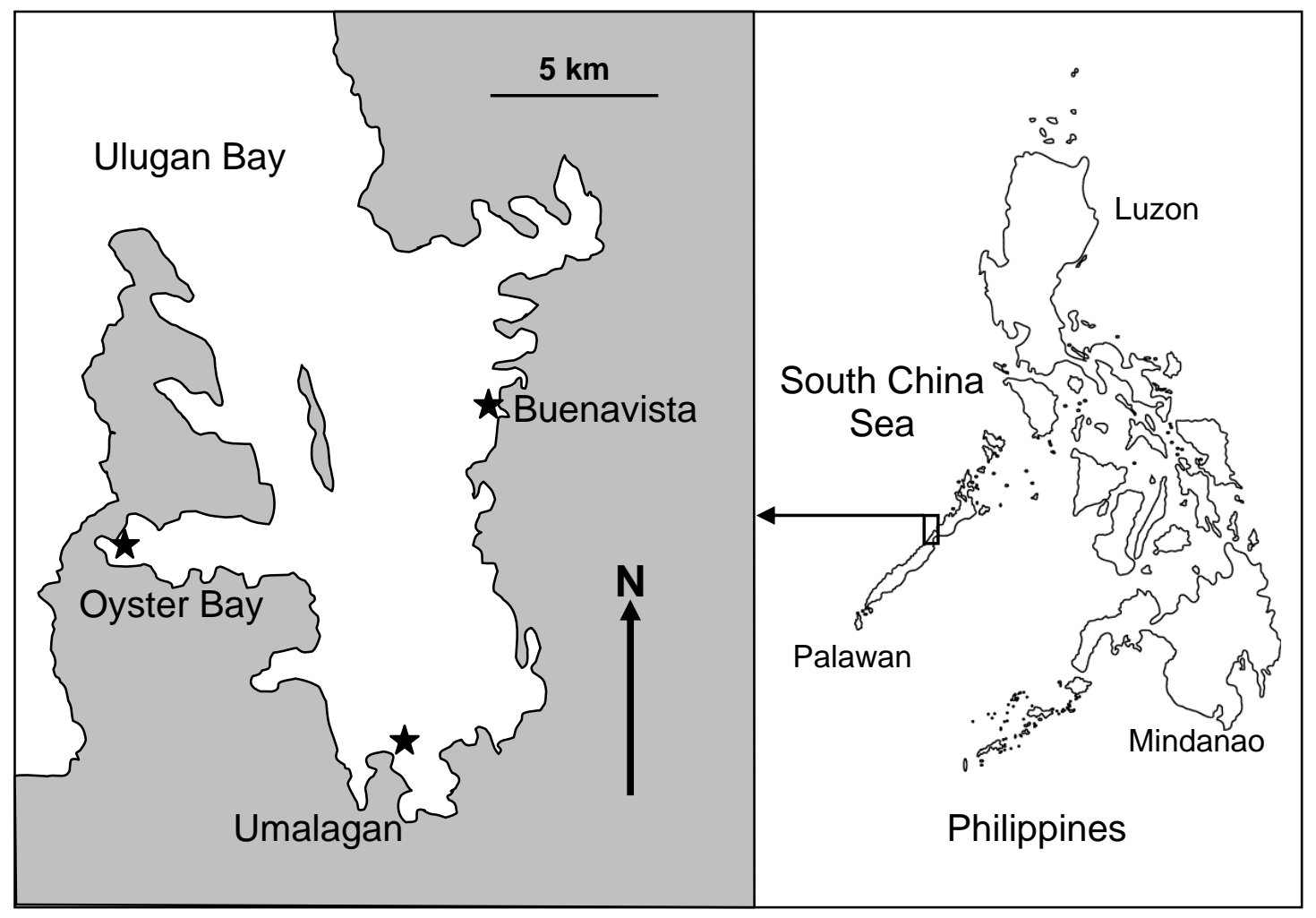

Fig. 1 Padilla et al. 


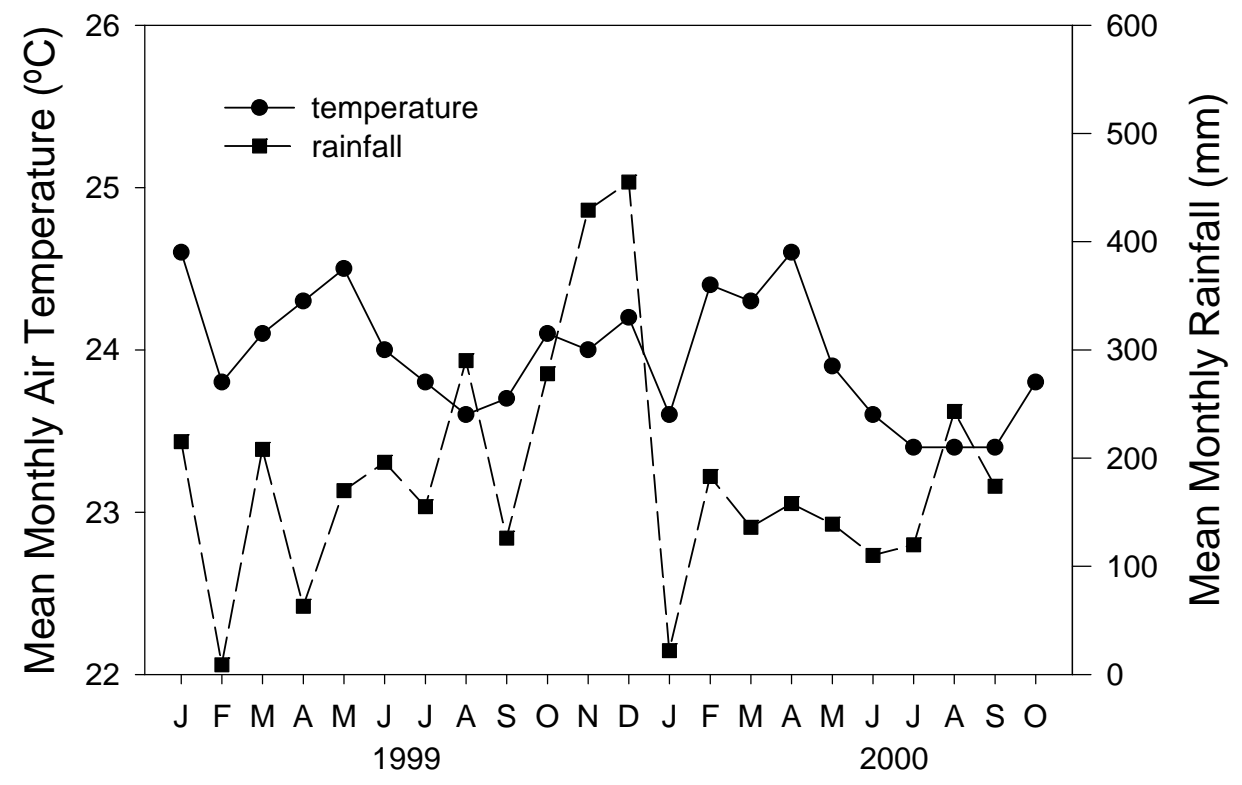

Month

Fig. 2 Padilla et al. 


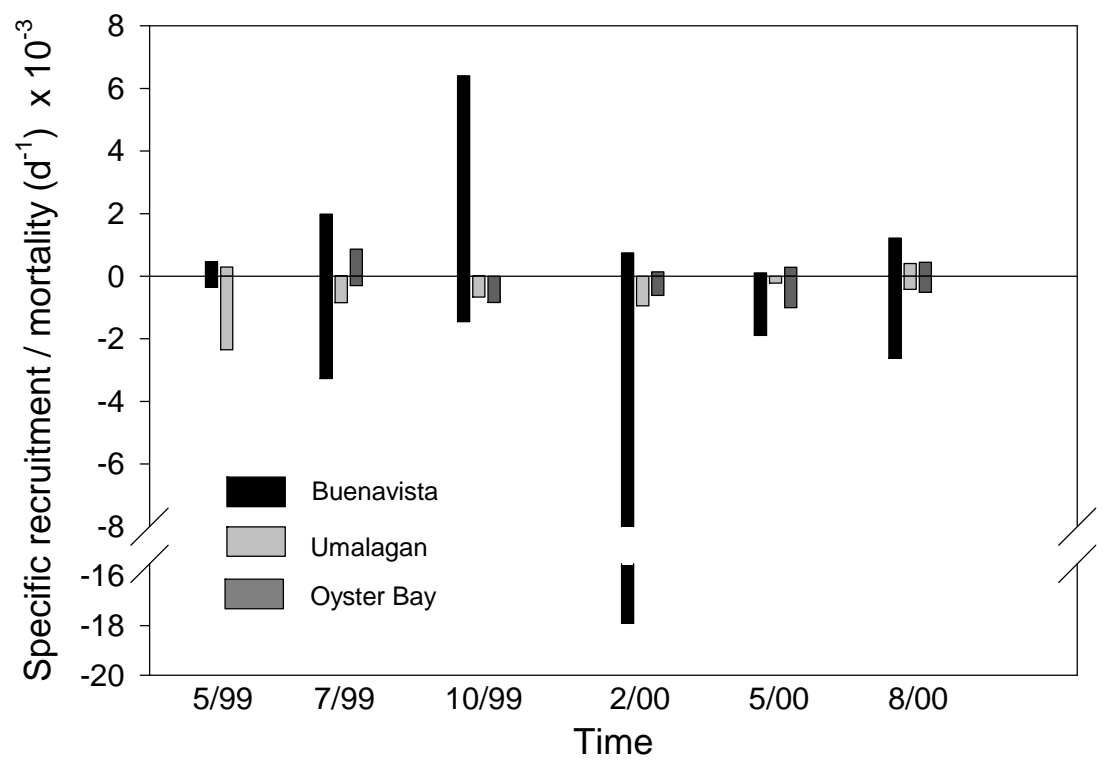

Fig. 3 Padilla et al. 


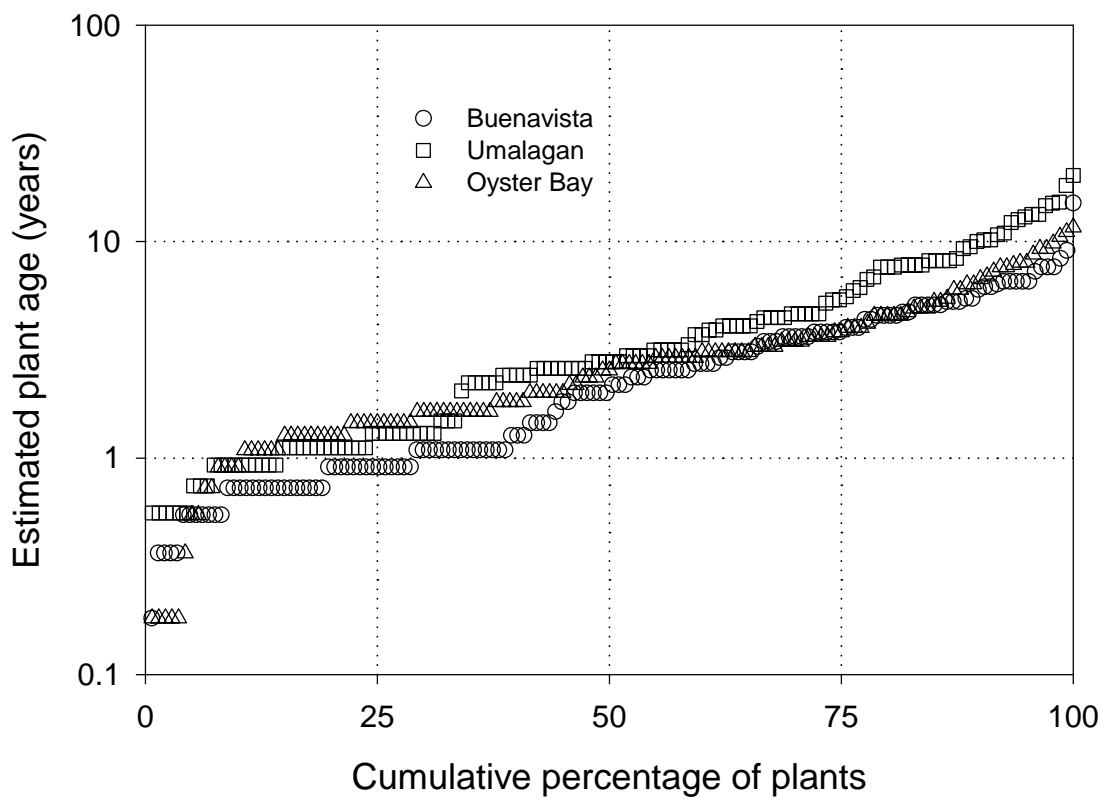

Fig. 4 Padilla et al. 

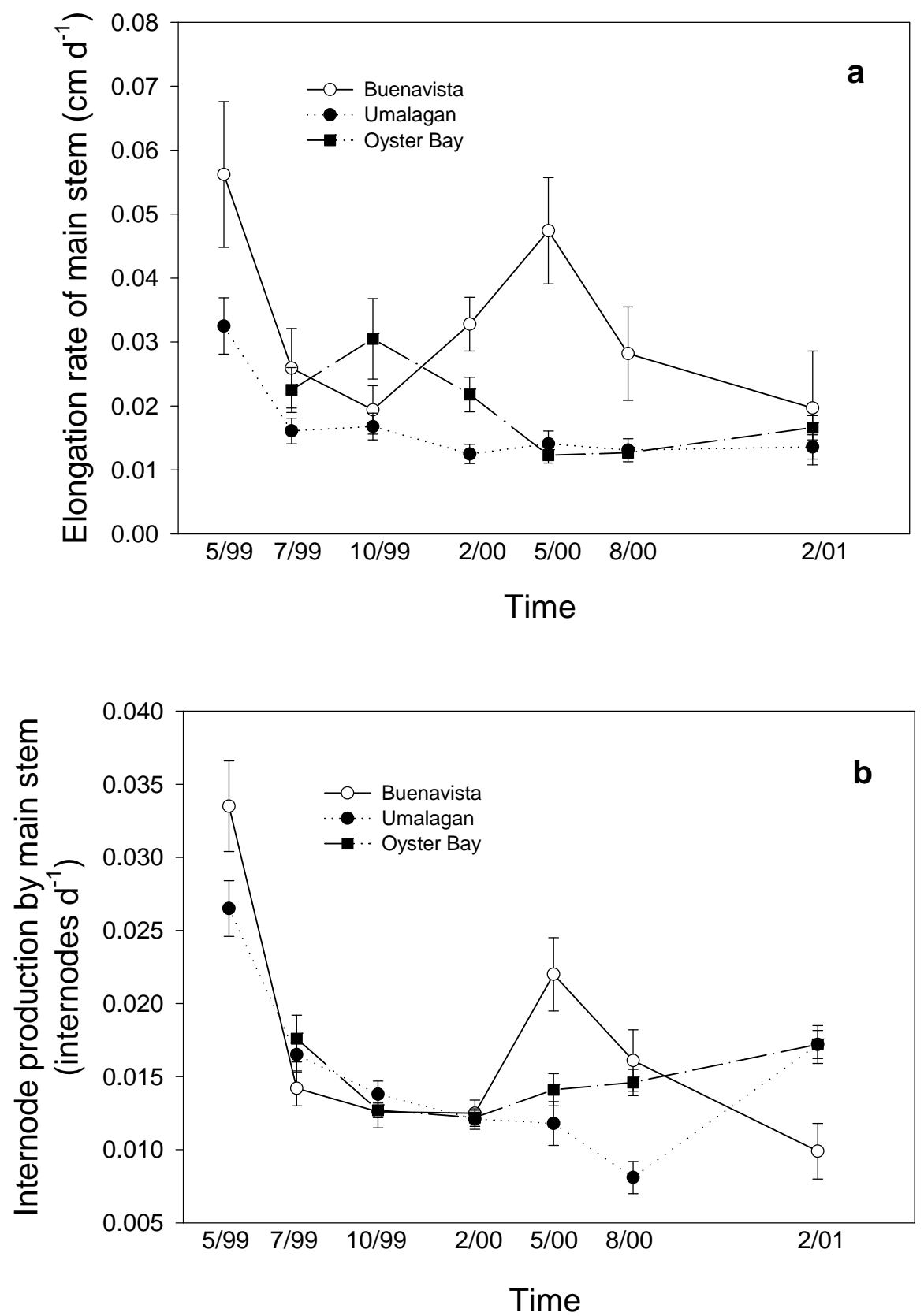

Fig. 5 Padilla et al. 